Article

\title{
Material Cycle of Agriculture on Miyakojima Island: Material Flow Analysis for Sugar Cane, Pasturage and Beef Cattle
}

\section{Shuichi Tamura ${ }^{1, *}$ and Koichi Fujie ${ }^{2}$}

1 Graduate School of Environment and Information Sciences, Yokohama National University, Sogo-Kenkyu-Tou Room S407, 79-7 Tokiwa-dai, Hodogayaku, Yokohama-city 240-850, Japan

2 Center for Risk Management and Safety Sciences, Faculty of Environmental and Information Sciences, Yokohama National University, Sogo-Kenkyu-Tou Room S407, 79-7 Tokiwa-dai, Hodogayaku, Yokohama-city 240-850, JapanYokohama National University; E-Mail: fujie@ynu.ac.jp

* Author to whom correspondence should be addressed; E-Mail: tamura-shuichi-jg@ynu.jp; Tel.: +81-45-339-4000; Fax: +81-45-339-4003.

Received: 18 November 2013; in revised form: 10 February 2014 / Accepted: 11 February 2014 / Published: 20 February 2014

\begin{abstract}
Agriculture on Miyakojima Island is highly dependent on imported fertilizer and feed. To reduce this dependence, the present research examines the biomass resources on the island by conducting a material flow analysis of stockbreeding and other related systems. To accurately quantify the amount of available biomass resources, loss ratios of the storage and composting processes are established. Then, a material flow analysis of a composting facility is made. Finally, current material flows between beef cattle, sugar cane and pasturage are shown. Based on this research, two proposals are made: the first is to use urine as liquid fertilizer, which is currently being done in Saga prefecture. The precedent of using urine as fertilizer is now widely accepted in the Saga area; is considered to be readily adoptable in other areas and could be substituted for the imported fertilizers on Miyakojima Island. The second is to use more residues of sugar cane for the beef cattle feed when the pasturage growth is slow in the winter. The present research suggests that the silage feeds for beef cattle.
\end{abstract}

Keywords: material flow analysis; material cycle; biomass resource utilization 


\section{Introduction}

Miyakojima Island is located 300 kilometers southwest of Okinawa Main Island as shown in Figure 1. The area of the island is $226 \mathrm{~km}^{2}$ and the climate of Miyakojima Island is subtropical. Most of area is flat, which makes the island suitable for agriculture. Agriculture on Miyakojima Island consists of agricultural crops, such as sugar cane, and stockbreeding, such as cattle breeding and raising. The agricultural crops in the island are sugar cane, pasturage, leaf tobacco, bitter melons and mangos. This paper follows our previous research "An Evaluation of the Cattle Raising Business in Miyakojima Island: Material Flow Analysis about Four Types of Cattle Raising [1]". Our focus is on a regional scale agricultural production system. This approach is based on the Zero Emission Initiative made by the United Nations University [1]. The key concept for this approach is "governance for local and regional sustainability". In the research done under the Zero Emission Initiatives, the focus was placed on the importance of the material cycle (in other words, recycling of materials).

Figure 1. Location of Miyakojima Island.

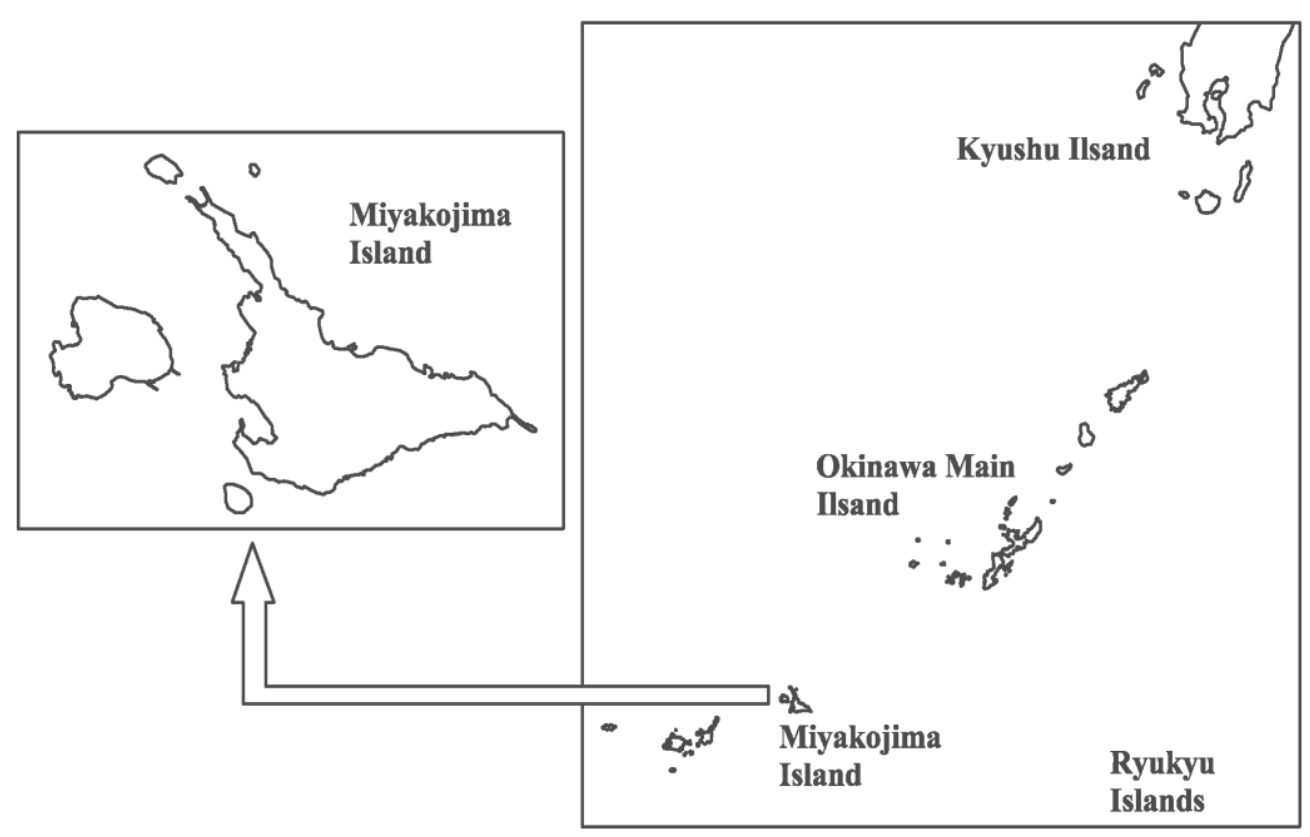

The present research conducts Material Flow Analysis (MFA) of cattle breeding and raising and sugar cane on Miyakojima Island. The MFA is an effective methodology to and to suggest a solution by looking at the entire picture of the targeted materials.

The present research specifically targets the nitrogen, carbon and phosphorus flows. Nitrogen is essential to the construction of protein, which is essential for activities of biological organisms including both agricultural crops and stockbreeding. Carbon is used to generate essential substances for life activity such as carbohydrates, fats and fibers. Phosphorus is used for energy metabolism or genetic mechanisms, forming ATP and DNA. Note that the material balance of nitrogen, carbon and phosphorus in the MFA for the present research is performed (e.g., the value of nitrogen input to beef cattle is equal to that of the nitrogen output from the beef cattle).

The present research performs the following three tasks with respect to agriculture on Miyakojima Island. (1) Conducts material flow analysis for stockbreeding, which generates biomass resources, 
sugar mills and a composting facility called "Miyakojima City Resources Recycling Center" respectively. (2) Quantifies the material cycle between beef cattle, and pasturage and sugar cane, as shown in Figure 2, and (3) Makes proposals for improvement of the stockbreeding system and the agricultural system: The proposals would make the stockbreeding and agricultural system less dependent on the resources from the outside of the island for independency.

Material cycle is the key concept that improves material efficiency in the interest of agricultural sustainability.

Figure 2. Concept of the material cycle between beef cattle, and pasturage and sugar cane.

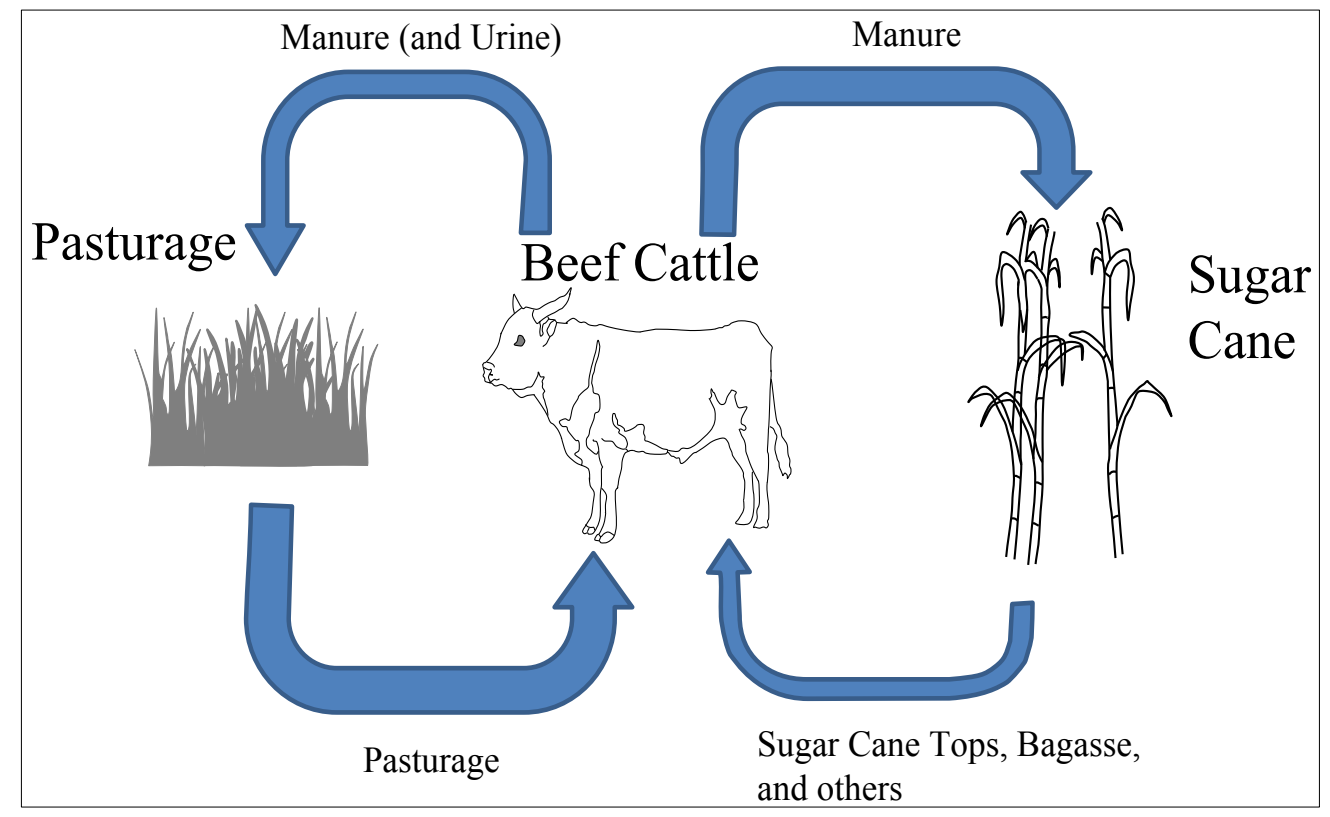

Our final goal at the end of a series of research projects is, including this research project, to establish a more independent and sustainable agricultural production model, which achieves more independence, and the present research is a part of this effort for Miyakojima Island. Note that this research addresses materials that are imported to and exported from the island in the MFA.

The present research primarily is based on the data of the Japanese Fiscal Year 2010, i.e., from April of 2010 to March of 2011.

\section{Methodology}

For the MFA, we conducted the following tasks; (1) interviewed farmers and city hall officials who are involved in the stockbreeding breeding and raising and agricultural plants; on-site investigations; (2) obtained statistical data, government documents, and stockbreeding farmers' administrative documents; and lastly, (3) conducted elemental analysis of agricultural crop residues. For analytical methods, see Table 1. Regarding determination of crude protein, after the nitrogen content is determined by $\mathrm{CHN}$ analyzer, a nitrogen-to-protein conversion factor is utilized (this conversion factor is commonly used in food analysis industry). Nitrogen Free Extract is obtained by the conversion factor which is commonly used in the food analysis industry (Nitrogen Free Extract $=100-$ (Crude Protein + Crude Fat + Crude Fiber + Crude Ash). 
Table 1. Analytical method.

\begin{tabular}{ll}
\hline \multicolumn{1}{c}{ Item } & \multicolumn{1}{c}{ Method } \\
\hline Water content & freeze dryer \\
carbon, nitrogen & elemental CHN analyzer, Vario EL III \\
phosphorus & molybdenum blue method \\
crude fat & diethyl ether extraction method \\
crude fiber & standard analysis method of AOAC (Association of Official Analytical Chemists) \\
sodium and potassium & atomic absorption spectrophotometry \\
calcium and magnesium & ICP atomic emission spectroscopy \\
\hline
\end{tabular}

Because the present research examined many materials, the research uses for factors estimating feed composition and nutrition composition such as (crude) protein, (crude) fat, (crude) fiber, that are shown in Appendix 1. The information sources are shown in Table 2, except for the beef cattle and pasturage. For information about them, refer to "An Evaluation of the Cattle Raising Business in Miyakojima Island" in reference 2.

Now we summarize the data provided in Table 2. The weight information for stockbreeding is obtained from the Miyako Meat Center. Quantities of feeds for stockbreeding are obtained from stockbreeding farmers. The number of stockbreeding animals is obtained from Miyakojima City Hall. The quantity of manure and urine generated by stockbreeding is obtained from the formula of Appendix 3. The information on N, C and P content of manure and urine of stockbreeding is obtained from references. The gas from stockbreeding is obtained from the equation, "(all input of $\mathrm{C}$ or $\mathrm{N})-($ all output of C or N other than gas)".

The information on residues generated from sugar mills is provided by two sugar mills. The information on content of bagasse, molasses, sugar cane tops and sugar are obtained from Japan Standard Tables of Food Composition (2010) and Standard Tables of Feed Composition in Japan (2009) $[2,3]$. We analyzed the filter cakes and trash. The information on the quantity of biomass from sugar cane is obtained from two sugar companies, a composting facility and reference [4]. The reference [4] was prepared by Miyakojima City Hall and provided for this research.

Table 2. Sources of information for material flow analysis (MFA).

\begin{tabular}{|c|c|c|c|}
\hline Item & References & Private Communications & Others \\
\hline number of stockbreeding & $\mathrm{n} / \mathrm{a}$ & Miyakojima city hall & $\mathrm{n} / \mathrm{a}$ \\
\hline weight of stockbreeding & $\mathrm{n} / \mathrm{a}$ & $\begin{array}{l}\text { the farmer(dairy cattle, } \\
\text { chicken), Miyako Meat } \\
\text { Center(pig) }\end{array}$ & $\mathrm{n} / \mathrm{a}$ \\
\hline $\begin{array}{l}\text { information for N, C and P } \\
\text { content of stockbreeding's } \\
\text { live body }\end{array}$ & $\begin{array}{c}{[5,6] \text { (pig P }} \\
\text { content only ) } \\
{[7] \text { (chicken P }} \\
\text { content only) }\end{array}$ & $\mathrm{n} / \mathrm{a}$ & $\mathrm{n} / \mathrm{a}$ \\
\hline $\begin{array}{l}\text { quantity of manure and urine } \\
\text { of stockbreeding }\end{array}$ & $\mathrm{n} / \mathrm{a}$ & $\mathrm{n} / \mathrm{a}$ & formula in Figure A2 \\
\hline $\begin{array}{l}\text { information on } \mathrm{N}, \mathrm{C} \text { and } \mathrm{P} \text { content } \\
\text { of manure and urine } \\
\text { of stockbreeding }\end{array}$ & {$[8-10]$} & $\mathrm{n} / \mathrm{a}$ & $\mathrm{n} / \mathrm{a}$ \\
\hline
\end{tabular}


Table 2. Cont.

\begin{tabular}{|c|c|c|c|}
\hline Item & References & Private Communications & Others \\
\hline quantity of feeds for stockbreeding & $\mathrm{n} / \mathrm{a}$ & Stockbreeding farmers & $\mathrm{n} / \mathrm{a}$ \\
\hline $\begin{array}{l}\text { information for } \mathrm{N}, \mathrm{C} \text { and } \mathrm{P} \\
\text { content of feeds for stockbreeding }\end{array}$ & {$[2,3]$} & $\begin{array}{l}\text { JA Okinawa Mainland } \\
\text { (about label of the product) }\end{array}$ & $\mathrm{n} / \mathrm{a}$ \\
\hline gas from stockbreeding & $\mathrm{n} / \mathrm{a}$ & $\mathrm{n} / \mathrm{a}$ & $\begin{array}{c}=(\text { all input of } \mathrm{C} \text { or } \mathrm{N})- \\
\text { (all output of } \mathrm{C} \text { or } \mathrm{N} \\
\text { other than gas) }\end{array}$ \\
\hline $\begin{array}{l}\text { quantity of residues from sugar } \\
\text { mills/ from sugar cane field }\end{array}$ & [4] & $\begin{array}{l}\text { two sugar companies, a } \\
\text { composting facility }\end{array}$ & $\mathrm{n} / \mathrm{a}$ \\
\hline $\begin{array}{l}\text { quantity of consumed sugar } \\
\text { cane tops }\end{array}$ & $\mathrm{n} / \mathrm{a}$ & sugar cane farmers & $\mathrm{n} / \mathrm{a}$ \\
\hline $\begin{array}{l}\text { information for } \mathrm{N}, \mathrm{C} \text { and } \mathrm{P} \text { content } \\
\text { of residues from sugar mills }\end{array}$ & {$[2,11,12]$} & $\mathrm{n} / \mathrm{a}$ & $\begin{array}{l}\text { elemental analysis, } \\
\text { label of the product } \\
\text { (crude sugar) }\end{array}$ \\
\hline $\begin{array}{l}\text { quantity of green manure plants } \\
\text { and its } \mathrm{N}, \mathrm{C} \text { and } \mathrm{P} \text { contents }\end{array}$ & {$[13,14]$} & Miyakojima City Hall & $\mathrm{n} / \mathrm{a}$ \\
\hline $\begin{array}{l}\text { quantity of residues from fishery } \\
\text { and its } \mathrm{N}, \mathrm{C} \text { and } \mathrm{P} \text { contents }\end{array}$ & [3] & a composting facility & $\mathrm{n} / \mathrm{a}$ \\
\hline $\begin{array}{l}\text { quantity of residues from pruned } \\
\text { trees and its } \mathrm{N}, \mathrm{C} \text { and } \mathrm{P} \text { contents }\end{array}$ & $\mathrm{n} / \mathrm{a}$ & $\begin{array}{l}\text { a composting facility, } \\
\text { Miyakojima City Hall }\end{array}$ & elemental analysis \\
\hline $\begin{array}{l}\text { quantity of lees from Awamori } \\
\text { Plants/ Residues from Methane } \\
\text { Fermentation Plants }\end{array}$ & $\mathrm{n} / \mathrm{a}$ & $\begin{array}{l}\text { a composting facility, } \\
\text { Miyakojima City Hall }\end{array}$ & $\mathrm{n} / \mathrm{a}$ \\
\hline $\begin{array}{l}\mathrm{N}, \mathrm{C} \text { and } \mathrm{P} \text { content of lees from } \\
\text { Awamori plants/ residues from } \\
\text { methane fermentation plants }\end{array}$ & {$[2,15]$} & $\mathrm{n} / \mathrm{a}$ & elemental analysis \\
\hline $\begin{array}{l}\text { quantity of food wastes and its } \mathrm{N}, \\
\mathrm{C} \text { and } \mathrm{P} \text { contents }\end{array}$ & {$[11,16]$} & Miyakojima City Hall & $\mathrm{n} / \mathrm{a}$ \\
\hline
\end{tabular}

\section{Results and Discussion}

\subsection{MFAs of Various Items for Sugar Cane, Pasturage and Beef Cattle}

The final goals for this chapter are to demonstrate the material cycle between the cattle, pasturage and sugar cane and then, to propose ways to make the material flow more efficient. For these purposes, this section presents: (1) MFA for the poultry breeding and raising, MFA for the dairy cattle breeding and raising, the hog breeding and raising, sugar mills and the Miyakojima City Resources Recycling Center. The target period in this research for all MFAs given above is one year except for the Miyakojima City Resources Recycling Center. (2) Establishment of loss ratios for composting at composting facilities and in the soil. (3) Applied fertilizer and biomass resource allocations to sugar cane and pasturage.

Manure from stockbreeding of beef cattle, dairy cattle, pigs, and chicken are plowed under as a basal fertilizer. Residues from sugar cane fields and sugar mills are plowed under for composting. Note that stockbreeding manure and residues from sugar cane fields and sugar mills are plowed under 
because they are considered as fertilizers. Other biomass resources including sludge from sewage plants, waste from pruned trees, the fishery residues, food wastes and methane fermentation residues from Awamori (a distilled liquor in the island) plants are also used. Sludge from sewage plants is also plowed under for use as fertilizer whereas pruned trees, fishery residues, raw garbage and lees from Awamori are used as the raw materials for the composting facilities.

In previous research [17], we clarified the MFA for four types of cattle breeding and raising. It shows the MFA for the lifecycle of each type of cattle breeding and raising. We need the "annual" MFA for the four types of cattle breeding and raising for this discussion (see Appendix 2). What we need to consider is biomass information, including quantity of manure, nitrogen quantity of manure, carbon quantity of manure, phosphorus quantity of manure, quantity of urine, nitrogen quantity of urine, carbon quantity of urine and phosphorus quantity of urine.

We will now provide MFAs for three types of stockbreeding. The present research first examines the dairy cattle. One farmer raises dairy cattle and provides the milk to schools. Dairy cattle are fed imported concentrate feeds and imported roughages. The reason for imported feed is that dairy cattle (Holstein) eat pasturage grown in cold climates, such as Italian rye grass, alfalfa, and other grasses, few of which are cultivated on Miyakojima Island. As discussed above, concentrate feeds are not cultivated on Miyakojima Island. This agricultural system is not reliably sustainable, as the farmer went bankrupt in September 2013, partially because procurement of all feed depended on the resources coming from outside of the island. The MFA for dairy cattle is shown in Figure $3[2,3,5,8,9,11]$.

Figure 3. MFA for the dairy cattle.



To obtain the quantity of manure from dairy cattle, we use an improved formula to obtain the quantity of manure as well as urine production of Stockbreeding. See Appendix 3. This formula is proposed in the previous research "An Evaluation of the Cattle Raising Business in Miyakojima Island: Material Flow Analysis about Four Types of Cattle Raising [17]", but is slightly adjusted to the need of the present study: the previous research only deals with cattle production whereas the present research deals with dairy cattle, poultry and hogs as well. 
When we actually obtain the quantity of each stockbreeding manure and urine from the formula, we need to use the values of Table 3 as well [8-10]:

Table 3. Nitrogen concentrations and proportional quantities of stockbreeding of manure and urine.

\begin{tabular}{ccccc}
\hline & $\begin{array}{c}\text { Nitrogen } \\
\text { Concentration } \\
\text { of Manure: } \\
\text { Wet Matter }\end{array}$ & $\begin{array}{c}\text { Nitrogen } \\
\text { Concentrati } \\
\text { on of Urine: } \\
\text { Wet Matter }\end{array}$ & $\begin{array}{c}\text { Proportion of Each Type } \\
\text { of Stockbreeding's } \\
\text { Manure against their } \\
\text { Urine: Wet Matter }\end{array}$ & $\begin{array}{c}\text { Proportion of Each Type } \\
\text { of Stockbreeding's Urine } \\
\text { against their Manure: } \\
\text { Wet Matter }\end{array}$ \\
\hline Beef Cattle & 0.0035 & 0.008 & 15 & 4 \\
Chicken & 0.0115 & N/A & 1 & N/A \\
Dairy Cattle & 0.0035 & 0.008 & 25 & 6 \\
Pigs & 0.0074 & 0.004 & 1 & 1 \\
\hline
\end{tabular}

The quantity of manure production is $25 \mathrm{~kg} /$ day, according to "Stockbreeding Great Encyclopedia" [9]. The quantity of manure for dairy cattle for this research is $20 \mathrm{~kg} /$ day but it would be within acceptable range. The MFA includes manure production when dairy cattle are still calves. Therefore, the quantity of the manure is expected to be smaller. "Sustaining living cows" in the MFA means the substances which are required to sustain the living dairy cattle. The lifespan of dairy cattle is 8 years. Feed is imported from outside the island, while meats and dairy cattle can be exported from the island.

Now we will take a look at the MFA of sugar mills in Figure 4 [2,3,5,11] prior to looking at the other types of stockbreeding. There are three sugar mills on Miyakojima Island that are run by two companies. Most of sugar cane is harvested manually but some farmers use harvesters. Harvesters also collect dried leaves from the sugar cane fields but they are not processed in sugar production. They go out from the sugar mills as trash. Sugar production generates crude sugars, molasses, bagasse, and filter cakes. Crude sugars go to sugar mills off the island, which can create white sugar. Molasses is purchased as raw material for stockbreeding feeds by a buyer from the outside of the island because it has a sweet odor and useful minerals for stockbreeding feeds. Crude sugar and molasses are exported from the island. Much of the bagasse is used as fuel for power generation and meets almost all electricity needs for sugar production operations. Because ashes generated from power generation contain useful minerals for agriculture, they are plowed under by farmers or are used as raw materials for composting. A part of the rest of bagasse is consumed as a cattle feed but most of it is plowed under or is used as raw material for composting. Trash and filter cakes are plowed under or are used as raw materials for composting.

We will clarify MFA for poultry breeding and raising. See the Figure 4 [2,3,8,9,11].

The majority of chickens, 30,598 out of a total of 31,738 chickens, are raised by one large farm. They are fed with imported concentrate feeds. Because chickens can only eat cereal, they are fed concentrate feeds, which consist primarily of cereals like corn. Miyakojima Island is not suitable for cultivation of cereals other than sweet potatoes. The present research does not discuss whether poultry breeding and raising with sweet potatoes is possible or not. Chickens are raised primarily for eggs, not meat. In FY 2010, farmers chose to dispose of half of the chickens as industrial waste rather than consuming them as meat. However, according to private communications with the large farmer, all chickens are currently consumed as meat. To sustain 31,738 chickens per year, the materials shown in 
Figure 5, "Sustaining Living Chicken", are necessary. Stockbreeding of an animal that has a life cycle longer than one year needs this type of substance output in the MFA.

Figure 4. MFA for sugar mills.

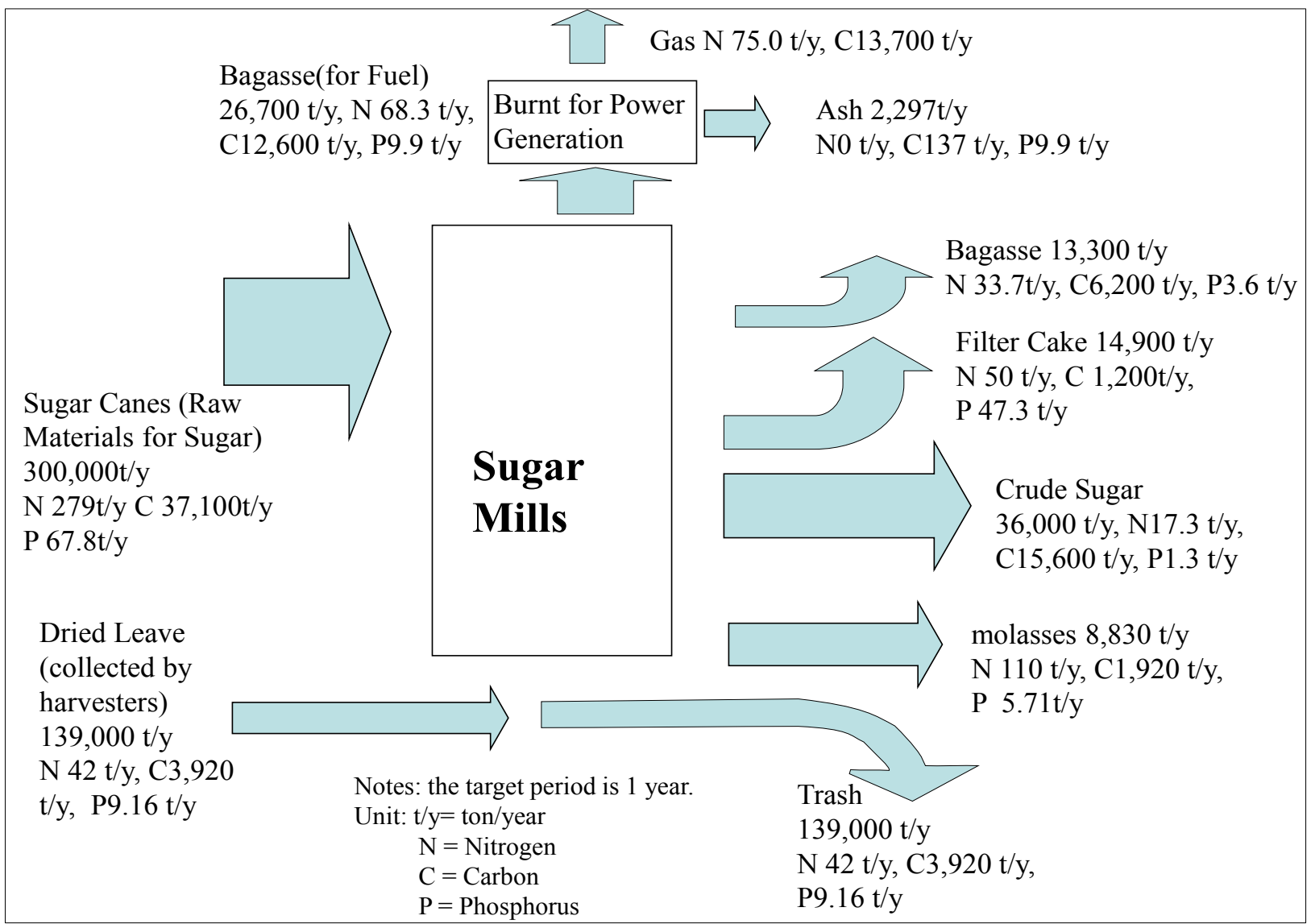

Figure 5. MFA for the poultry breeding.



We next show the MFA for hog breeding and raising in Figure 6 [2,3,6-12,15,16]. Pigs on Miyakojima Island are primarily fed food wastes from restaurants, supermarkets, hotels, and so on and 
do not need to be fed imported concentrate feeds. However, lees from Awamori production, which is done with imported broken rice from Thailand, is given to them. Imported feeds are concentrate feeds created from corn, wheat bran, food oils, fish, pork, and so on. The purpose of the concentrate feed provision is to reduce fats from pigs before they are shipped to the Miyako Meat Center. This can raise the price of pigs. The quantity of manure production is $2.08 \mathrm{~kg} /$ day. According to "Stockbreeding Great Encyclopedia" [9], the quantity should be $3 \mathrm{~kg} /$ day but it would be within the acceptable range. The MFA includes manure production when pigs are still piglets, so the quantity of the manure is expected to be smaller. The quantity after the storage process will become $1 \mathrm{~kg} /$ day according to a farmer in Okinawa Main Island. If the quantity of raw manure is $3 \mathrm{~kg} / \mathrm{day}$, the required quantity loss ratio quantity of manure in the storage process would be $66.7 \%$.

Figure 6. MFA for the hog breeding and raising.

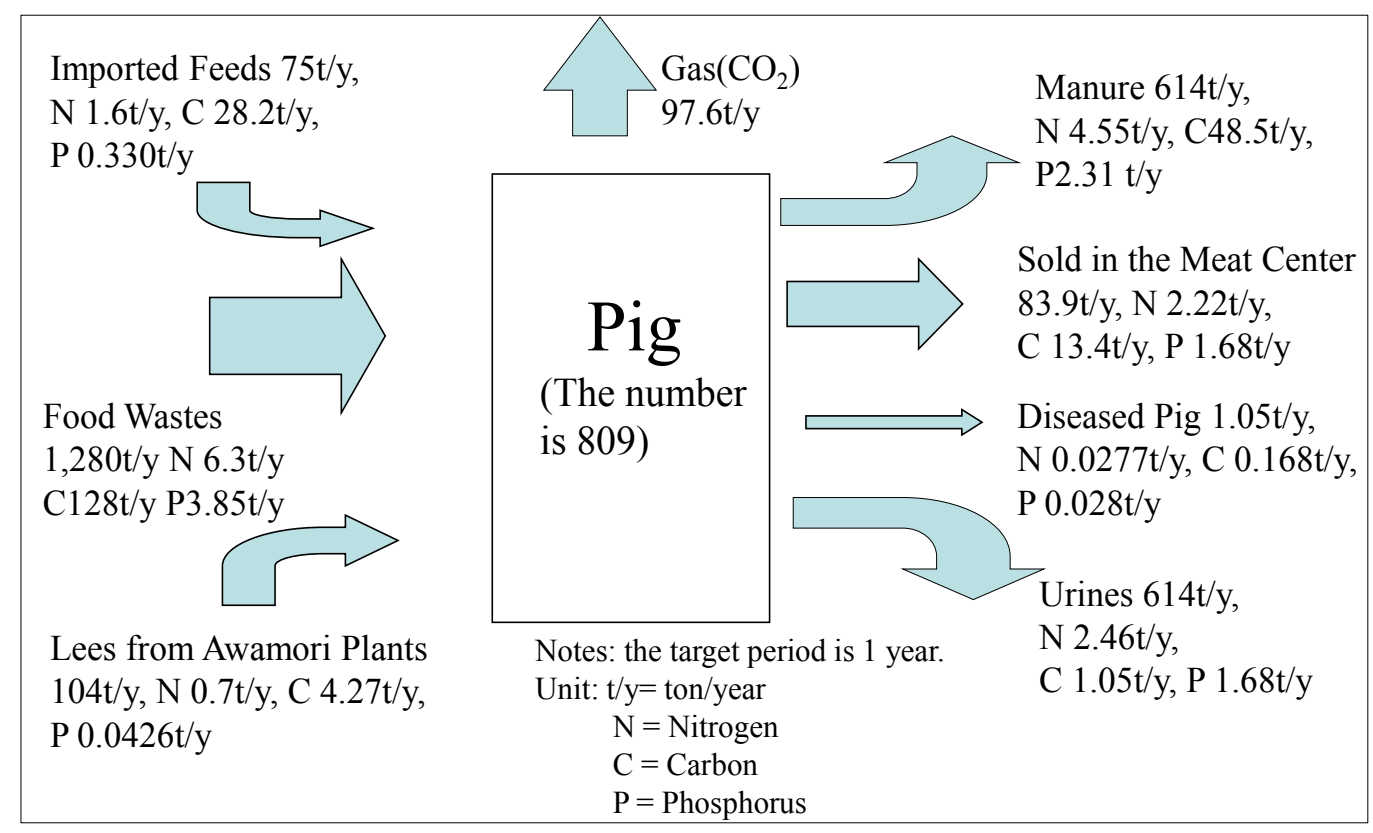

The primary purpose of the discussion above is to determine the quantity of biomass resources, i.e., manure from stockbreeding, which can go to sugar cane. Now we can determine other biomass resources with the MFA for sugar mills, i.e., residues from sugar mills such as bagasse, filter cakes, trash and ash. Other biomass resources which go to sugar cane, such as pruned trees, methane fermentation residues from Awamori plants, sludge from sewage plants, and green manures, are determined in the later part of this section. Note that not all biomass resources go to sugar cane. We will discuss the quantity of biomass resources that go to sugar cane at the end of this section.

Next, we would like to demonstrate the MFA of Miyakojima City Resources Recycling Center. The purpose is to establish the fraction of materials and substances that were lost in the process of composting conducted in three composting facilities of Miyakojima Island. We also need to establish the quantity of loss in the storage process. Note that loss in the storage process is caused by decomposition of microbes: organic matters are decomposed and primarily emit carbon, nitrogen, hydrogen and oxygen gas. Private communication with the stockbreeding farmers revealed that mixing manure for composting is not conducted except in the three composting facilities. For examples, most cattle breeding and raising farmers cultivate sugar cane at the same time as sugar cane cultivation and 
therefore they use manure as fertilizer for sugar cane cultivation. They place manure in the storage without mixing procedures for composting and plow under the manure for the sugar cane fields one month prior to planting sugar cane so that substances contained in the manure that are harmful to the sugar cane growth are decomposed by the bacteria in the soil. A few cattle breeding and raising farmers and one poultry breeding and raising farmer use two composting facilities with their manure for sale or for bagasse which is used as bedding material: one composting facility always keeps bagasse to exchange it for cattle manure. Another composting facility is not able to obtain any manure from stockbreeding farmers and so it uses the fishery residues instead.

First, we try to establish the quantity loss in the storage process. One farmer raises 200 calves and 300 breeding cows (beef cattle); the quantity of raw manure was ascertained in previous research [17]. Also the quantity of manure stored is kept in the administrative records of the farmer: the quantity of raw manure is $2,440 \mathrm{t} / \mathrm{y}$ while the quantity of stored manure is $1,500 \mathrm{t} / \mathrm{y}$. Therefore we estimate that the loss ratio of quantity of beef cattle and dairy cattle is $38.7 \%$. Since there are no reliable records on Miyakojima Island, we adopt the value from "Estimation of Flow Sheet and Load Unit to Farm Soils of Nitrogen Excreted by Animals on the Basis of the National Statistical Data" regarding the nitrogen loss ratio [18]. Note that we adopt the value of dairy cattle for the beef cattle i.e., $10.3 \%$ because the loss ratio of dairy cattle is greater than that of beef cattle and because the storage term of beef cattle is thought to be longer than any other type of stockbreeding according to personal communications with stockbreeding farmers.

Regarding the loss ratio for chickens, the quantity of raw manure of the large farmer is $1,100 \mathrm{t} / \mathrm{y}$ while the quantity of stored manure is $903 \mathrm{t} / \mathrm{y}$ : therefore the loss ratio for chicken manure production is $19.1 \%$.

Regarding the loss ratio for pigs, we were not able to obtain the information on Miyakojima Island but obtained it from a farmer on Okinawa Main Island (see Figure 1) who raises hogs with food wastes and was able to provide the relevant information: The quantity of stored manure is $295 \mathrm{t} / \mathrm{y}$ as shown in Figure 6, and the quantity of raw manure of hog breeding and raising is $737 \mathrm{t} / \mathrm{y}$. Therefore the loss ratio for pigs is $59.9 \%$.

Note that the storage period for chickens are considered to be 0.5 month. But the storage period of the beef cattle/dairy cattle and pigs is 5-6 month, and is primarily used as the basic fertilizer for sugar canes, which are planted one time a year. Almost all manure from chicken goes to two composting facilities once per month. Therefore the loss ratio for chickens is relatively low when compared with other loss ratios in Table 4: however, because research studies for loss ratios of stockbreeding manure are few in number, we think further research will be necessary.

Table 4. Quantity and substance loss ratio of manure in the storage process.

\begin{tabular}{lcccc}
\hline & Quantity (\%) & Nitrogen (\%) & Carbon (\%) & Phosphorus (\%) \\
\hline Beef Cattle / Dairy Cattle & 38.7 & 10.3 & 13.1 & $0 \%$ \\
Chicken & 18.1 & 8.4 & 10.7 & $0 \%$ \\
Pig & 59.9 & 14.7 & 18.7 & $0 \%$ \\
\hline
\end{tabular}

Regarding the carbon loss ratio of composting process of manure and urine, this information is available in the research "Carbon, Nitrogen Balances and Greenhouse Gas Emission during Cattle Feedlot Manure Composting" [19]. The proportion between nitrogen loss and carbon loss in the research is applied to the quantity of carbon and nitrogen quantity for each type of stockbreeding in 
Figures 3-7. Although the result is obtained from cattle breeding and raising, it is applied to the other types of stockbreeding for the convenience of this discussion.

In this research, when the nitrogen loss is $8.3 \mathrm{~kg}$, the carbon loss is $174 \mathrm{~kg}$. Accordingly, the carbon loss ratios are obtained as shown in the Table 4.

Table 5 shows the nitrogen, carbon and phosphorus concentrations of stockbreeding manure after the storage process. Manure from each stockbreeding loses total quantity of nitrogen and carbon. However, concentrations themselves are increased by the storage process.

Table 5. Nitrogen, carbon and phosphorus concentrations of stockbreeding manure after the storage process.

\begin{tabular}{lccc}
\hline & $\begin{array}{c}\text { Nitrogen Concentration of } \\
\text { Manure: Wet Matter (\%) }\end{array}$ & $\begin{array}{c}\text { Carbon Concentration of } \\
\text { Manure: Wet Matter (\%) }\end{array}$ & $\begin{array}{c}\text { Phosphorus Concentration } \\
\text { of Manure: Wet Matter (\%) }\end{array}$ \\
\hline Beef Cattle & 0.51 & 8.51 & 0.183 \\
Dairy Cattle & 0.397 & 6.01 & 0.0667 \\
Chicken & 2.64 & 23.5 & 0.621 \\
Pigs & 1.58 & 16 & 0.938 \\
\hline
\end{tabular}

With these concentration values in mind, we turn to the MFA for the Miyakojima City Resources Recycling Center. The purpose of this MFA is to establish the, nitrogen and carbon loss ratios of the raw materials, which are processed in the three composting facilities. The target period of the MFA of Miyakojima City Resources Recycling Center is five years because the loss ratios among years are variable. The reasons for variability of the loss ratios are because (1) composting processes take a few months, (2) the period of high demands are during August or September, i.e., the application timing of base fertilization to sugar cane and (3) Composts are competitive with other composts and organic fertilizers from the inside and the outside of the island. Note that organic fertilizers are manure from stockbreeding but did not go through composting processes. It is usually a pellet dried by machines. To enhance the accuracy, the present research sets the target period as five years.

Now we show the MFA for the Miyakojima City Resources Recycling Center, as follows $[2,3,10,11,20]$.

As discussed above, one composting facility always keeps bagasse to exchange it for cattle manure, which is the Miyakojima City Resources Recycling Center. Two types of the composts are created at the Miyakojima City Resources Recycling Center, which are composts using chicken manure and composts using cattle manure. Another composting facility purchased manure from the biggest poultry breeding and raising farmer when this MFA of the poultry breeding and raising farm was conducted. Food waste is collected by the city together with other wastes from homes and businesses. The difference between food wastes for the composting facility and food wastes for hog breeding and raising is that the food wastes for the composting facility are usually decayed because they are stored at homes or at companies until they are collected by the city whereas food wastes for hog breeding and raising are collected daily from restaurants, hotels and supermarkets as addressed above. These food wastes are not fully used but they may be discussed in future research. 
Figure 7. MFA for the miyakojima city resources recycling center.

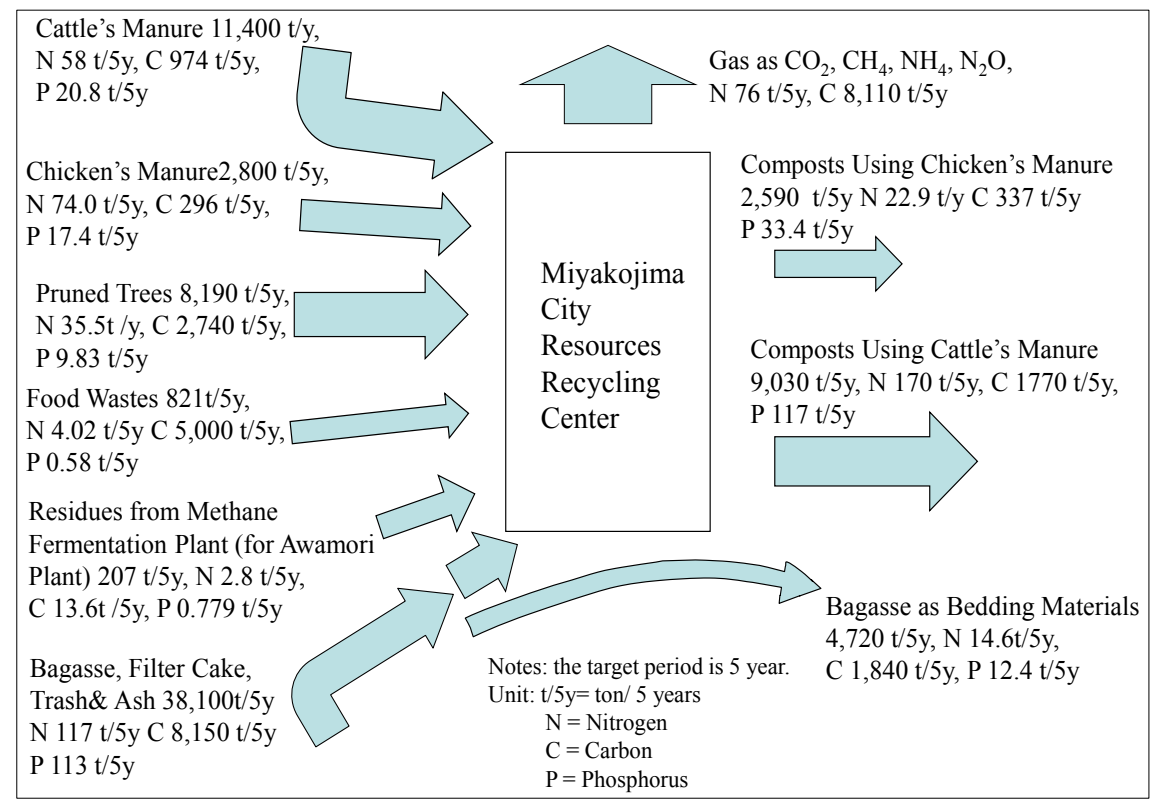

Waste from pruned trees are also collected by the city hall and are shredded into wood chips for composting and residues from sugar mills are purchased by the facility. Even if the public composting facility like Miyakojima City Resources Recycling Center does not need to compost residues from sugar mills, they are fully utilized by farmers who plow them under their farm soil. This topic may be discussed in future research. Regarding the residues from a methane fermentation plant, two Awamori plants own these and one of them has a composting facility that uses them as raw materials for composting.

The present research adopts the analytical results for the nitrogen and carbon concentrations provided by the composting facility: however, the analytical results for the phosphorus concentrations are not adopted for the convenience of the discussion: The phosphorus quantity of the input should be the same quantity as the output within the framework of the present research, because Miyakojima City Resources Recycling Center has the concrete floors and phosphorus in the input will not be lost

Now we are able to obtain the quantity, nitrogen and carbon loss ratios of the raw materials, which are processed at the three composting facilities, as shown in Table 6:

Table 6. Loss ratio establishment of all materials for composting in the facility.

\begin{tabular}{lcccc}
\hline & Quantity (\%) & Nitrogen (\%) & Carbon (\%) & Phosphorus (\%) \\
\hline Composting in the Facility & 73.4 & 26.1 & 78.6 & $0 \%$ \\
\hline
\end{tabular}

Another composting system that is used widely on Miyakojima Island uses residues from sugar mills and sugar cane fields. For the present research, we need to establish these loss ratios as well. The carbon-to-nitrogen ratio (hereafter, $\mathrm{C} / \mathrm{N}$ ratio) of the residues from sugar mills and sugar cane fields are high. No past research was done regarding loss ratios of the residues from sugar mills and sugar cane fields: however there was a study which determined the residual ratio of plants with the relatively high $\mathrm{C} / \mathrm{N}$ ratio are when they are plowed under. The research paper entitled, "Studies on Soil Science and Fertilizer in the Paddy Field Applied Rice and Barley Straw" [21], determines how much barley and rice straw remain when they are plowed under. For the convenience of this discussion, we use the 
residual ratios this report determines. The residues decompose relatively slowly and a nitrogen deficiency occurs. The nitrogen quantity in the residues increases because the residues absorb the nitrogen from the soil: $138 \%$ for barley and $95 \%$ for rice show the maximum values of nitrogen when 9.5 months elapse for barley and when 6 months elapse for rice. The nitrogen values $84 \%$ and $89 \%$ are the lowest values until 9.5 months for barley and 6 months for rice. Those are judged to show the nitrogen quantity that barley and rice residues lost. The present research adopts the values highlighted in bold face because they are conservative for this purpose. Note that Table 7 only applies to residues from sugar mills and residues from sugar cane. Because they cause a nitrogen deficiency, they are plowed under 6 months prior to the billet planting for sugar cane. On Miyakojima Island, billet planting for sugar cane is usually made in late August or early September.

Table 7. Residual ratio (of the residues from sugar cane) for composting when plowed under [19].

\begin{tabular}{ccccc}
\hline & Quantity (\%) & Nitrogen (\%) & Carbon (\%) & Phosphorus (\%) \\
\hline Barley (9.5 Months Elapsed) & $\mathbf{3 4 . 3}$ & $\mathbf{8 4}(138)$ & 55 & 100 \\
Rice (6 Months Elapsed) & 54.8 & $89(95)$ & $\mathbf{3 9 . 6}$ & 100 \\
\hline
\end{tabular}

Next, the present research tries to clarify how much biomass resources are plowed under. Note that Table 7 is applied to residues from sugar mills and residues from sugar cane while Table 5 is applied to stockbreeding's manure. Regarding sewage plant sludge and green manure plants, nothing is applied because it does not have any storage process and any composting process. There were two sewage plants in the island in FY 2010: one collects sludge from individual home septic tanks by tanker truck; the other collects sewage from sewage collection system lines. The present research adopts the $\mathrm{C} / \mathrm{N}$ ratio from sludge processed from sewage collected from the sewage collection system lines because the analysis of sludge collected from home septic tanks was not made. Table 8 shows biomass resources that are plowed under and incorporated into the soil. When we use the values in Table 4 and Table 7 together, we are able to obtain values for the quantity of biomass and the quantities of nutrients (nitrogen, carbon and phosphorus) that are used to fertilize agricultural plants on Miyakojima Island that are derived from biomass resources that are incorporated into the soil.

Table 8. List of biomass resources which are plowed under $[4,13,14]$.

\begin{tabular}{lcccc}
\hline & $\begin{array}{c}\text { Total } \\
\text { Quantity (t/y) }\end{array}$ & $\begin{array}{c}\text { Nitrogen } \\
\text { Quantity (t/y) }\end{array}$ & $\begin{array}{c}\text { Carbon } \\
\text { Quantity (t/y) }\end{array}$ & $\begin{array}{c}\text { Phosphorus } \\
\text { Quantity (t/y) }\end{array}$ \\
\hline Residues from Sugar Mills & 25,900 & 150 & 17,200 & 47 \\
Residues from Sugar Cane Fields & 201,000 & 812 & 56,500 & 133 \\
Beef Cattle's Manure & 69,200 & 242 & 4,150 & 68 \\
Chicken's Manure & 39.5 & 0.456 & 4.17 & 0.0984 \\
Dairy Cattle's Manure & 1,530 & 5.36 & 92 & 0.825 \\
Pig's Manure & 386 & 2.86 & 30.5 & 1.45 \\
Sewage Plant Sludge & 793 & 7.63 & 61.0 & 2.17 \\
Green Manure Plants & 42,800 & 61.3 & 1640 & N/A \\
Residues from Methane & 50 & 0.954 & 4.64 & 0.266 \\
Fermentation Plants & & & & \\
\hline
\end{tabular}


Table 9 shows biomass resources that are composted in three composting facilities. When we use the values in Table 6 and Table 9 together, we are able to obtain quantities of biomass resources and quantities of nutrients (nitrogen, carbon and phosphorus) that are used to fertilize agricultural plants on Miyakojima Island that are derived from compost.

Table 9. Biomass resource list for composting facilities.

\begin{tabular}{lcccc}
\hline & $\begin{array}{c}\text { Total } \\
\text { Quantity (t/y) }\end{array}$ & $\begin{array}{c}\text { Nitrogen } \\
\text { Quantity (t/y) }\end{array}$ & $\begin{array}{c}\text { Carbon } \\
\text { Quantity (t/y) }\end{array}$ & $\begin{array}{c}\text { Phosphorus } \\
\text { Quantity (t/y) }\end{array}$ \\
\hline Residues from Sugar Mills & 11,200 & 32 & 2,920 & 19.3 \\
Beef Cattle's Manure & 3770 & 40.2 & 791 & 4.59 \\
Chicken's Manure & 1,060 & 12.2 & 112 & 2.64 \\
Fishery Residues & 101 & 3.89 & 17.2 & 0.26 \\
Wastes from Pruned Trees & 4,360 & 18.9 & 1460 & 5.23 \\
Food Wastes & 189 & 0.93 & 18.9 & 0.134 \\
Lees from Awamori Plants/ Residues & 671 & 8.29 & 41.3 & 2.14 \\
from Methane Fermentation Plants & & & & \\
\hline
\end{tabular}

Table 10 shows a biomass resource from 300 pigs that is a slurry mixture of manure and urine used for vegetable cultivation:

Table 10. Pig's slurry and loss ratios $[13,19,22]$.

\begin{tabular}{lcccc}
\hline & $\begin{array}{c}\text { Total Quantity } \\
\text { and Loss Ratio }\end{array}$ & $\begin{array}{c}\text { Nitrogen Quantity } \\
\text { and Loss Ratio }\end{array}$ & $\begin{array}{c}\text { Carbon Quantity } \\
\text { and Loss Ratio }\end{array}$ & $\begin{array}{c}\text { Phosphorus Quantity } \\
\text { and Loss Ratio }\end{array}$ \\
\hline Pig's Slurry & $455 \mathrm{t} / \mathrm{y}$ & $2.60 \mathrm{t} / \mathrm{y}$ & $18.4 \mathrm{t} / \mathrm{y}$ & $1.4 \mathrm{t} / \mathrm{y}$ \\
Loss Ratio & $0 \%$ & $25 \%$ & $31.8 \%$ & $0 \%$ \\
\hline
\end{tabular}

Table 11 shows quantitates of imported chemical and organic fertilizers and composts. The information in Table 11 is based on the administrative data provided by Miyakojima city hall and JA Okinawa Miyakojima District. As you can see, chemical fertilizers contain a large amount of nitrogen. On the other hand, organic fertilizer tends to contain more carbon (Organic fertilizers are different from composts: They are usually created with machines while compost is created by microbial decomposition. Therefore most of "Organic Fertilizer and Compost" in Table 11 is occupied by one product: it is chicken's manure dried by machines. So the composition of "Organic Fertilizer and Compost" in Table 11 is relatively high). Regarding the carbon concentration of non-organic chemical fertilizers, manufacturers do not analyze chemical fertilizer for the carbon content because it is not required by regulations in Japan. Therefore, we rely on two methods for determining carbon content. When we know the active ingredients such as urea, we estimate the concentration from its chemical formula; and we also made chemical analysis of several fertilizers. We are able to estimate and analyze the carbon concentration from $86.4 \%$ of fertilizers by these two methods. For the carbon concentration of the remaining $13.6 \%$ of fertilizers, the present research assumes that they have the similar concentrations. 
Table 11. Imported fertilizer quantity.

\begin{tabular}{lcccc}
\hline & $\begin{array}{c}\text { Total } \\
\text { Quantity (t/y) }\end{array}$ & $\begin{array}{c}\text { Nitrogen } \\
\text { Quantity (t/y) }\end{array}$ & $\begin{array}{c}\text { Carbon } \\
\text { Quantity (t/y) }\end{array}$ & $\begin{array}{c}\text { Phosphorus } \\
\text { Quantity (t/y) }\end{array}$ \\
\hline Chemical Fertilizer & 5,940 & 1,000 & 217 & 202 \\
Organic Fertilizer and Compost & 3,870 & 96.7 & 1,090 & 59.1 \\
Total & 9,810 & 1,040 & 1,310 & 262 \\
\hline
\end{tabular}

Now we discuss the distribution of fertilizer and biomass resources shown in Table 12. This is based on interviews with farmers and the quantity of nitrogen contained in agricultural plants. Fertilizers are available for purchase by anyone, but biomass, like stockbreeding manures are unevenly distributed: usually sugar cane farmers keep beef cattle and they tend to use manure from them for their sugar cane fields. They own their own grass lands for pasturage cultivation. Farmers of other agricultural plants seem to purchase the manure from the farmers in stockbreeding. Otherwise, they obtain organic fertilizers or composts imported from outside of the island.

Table 12. Agricultural plant biomass ranking and fertilizer and biomass distribution ratio.

\begin{tabular}{lcccc}
\hline $\begin{array}{c}\text { Agricultural Plant } \\
\text { Name }\end{array}$ & $\begin{array}{c}\text { Nitrogen } \\
\text { Quantity of Each } \\
\text { Agricultural } \\
\text { Plant (t/y) }\end{array}$ & $\begin{array}{c}\text { Stockbreeding Manure's and } \\
\text { other Biomass (excluding } \\
\text { sugar cane residues) } \\
\text { Distribution Ratio (\%) }\end{array}$ & $\begin{array}{c}\text { Sugar Cane } \\
\text { Residue's } \\
\text { Distribution } \\
\text { Ratio (\%) }\end{array}$ & $\begin{array}{c}\text { Fertilizer } \\
\text { Distribution } \\
\text { Ratio (\%) }\end{array}$ \\
\hline Sugar Cane & 1,130 & 80.6 & $100 \%$ & 66 \\
Pasturage & 16.7 & 15.6 & $0 \%$ & 21 \\
Squash & 6.1 & $1.49 \%$ & $0 \%$ (negligible) & 5 \\
Leaf Tobacco & 20.9 & $0.435 \%$ & $0 \%$ (negligible) & 2 \\
Chinese Preserving & 12.2 & $0.991 \%$ & $0 \%$ (negligible) & 3 \\
Melon & 13.9 & $0.87 \%$ & $0 \%$ (negligible) & 2.5 \\
Bitter Melon & 16.7 & $0.0588 \%$ & $0 \%$ (negligible) & 0.5 \\
Mango & & & & \\
\hline
\end{tabular}

Sugar cane residues (meaning residues from sugar mills and residues from sugar cane fields) are exclusively used by sugar cane farmers except for the residues that go to composting facilities. Few farmers of the other agricultural plants use them for composting (see the relevant parts of Table 9).

Fertilizer utilization is not that straightforward. The present research allocates fertilizer use according to the results of interviews with farmers. In addition, "Okinawa Prefectural Government Fertilizer Application Standard" is referenced as well [23]. Note that the quantity of fertilizers is not precisely in agreement with the results of interviews. Adjustments are made, considering the nitrogen quantity that each plant has.

\subsection{Material Cycle between Stockbreeding and Agricultural Plants and Proposals for its Improvement}

Based on the discussion in the previous section, this research demonstrates the material cycle between beef cattle, pasturage and sugar cane anticipated in Figure 2 of Chapter 1.

In Figure 8, four areas are enclosed by red circles that show our proposals for improvement in the MFA. The first proposal shown on the right side of the Figure 8 is that urine should be substituted for imported fertilizers, thereby reducing the use of the imported fertilizer. 
Figure 8. MFA for the material cycle of beef cattle, sugar cane and pasturage.



Three material cycles are shown in Figure 8:

(1) One material cycle is made between sugar cane, pasturage, and the beef cattle. Pasturage and sugar cane are given as cattle feeds. Pasturage and sugar cane tops are fed directly to beef cattle. However, there is another material flow to feed beef cattle. That is, sugar cane goes to sugar mills and after crude sugars are created, they are given to cattle as residues from sugar mills. When pasturage and sugar cane are eaten and digested, they will become manure or urine. Urine may be evaporated into the air or seep into the solid and ground water. In a few cases, they are absorbed by bedding materials like bagasse and are used for the raw materials for composting. The quantity of the bagasse as bedding materials is judged to be negligible.

(2) The next material cycle is made between sugar cane and sugar mills. Sugar cane or manure from the beef cattle go to sugar cane and pasturage are used as material of composts in the facility. All of beef cattle's manure is used as raw materials of composting. As the basal fertilizer, manure is plowed within one month prior to billet plantings for sugar cane.

(3) The other material cycle is made between sugar cane and its soil. A large amount of leaves and sugar cane tops are left in the field. In April, farmers plow under their sugar cane residues together with bagasse, ash, trash and filter cakes that are from sugar mills, in order to promote decomposition and to create composts. For that purpose, plowing is done 6 times during half of the year until farmers plant sugar cane billets in late August or in early September. 
Sugar, and molasses are exportable commercial products derived from sugar cane, i.e., output from Miyakojima Island. Calves (beef cattle) and breeding cows (beef cattle) after are also exportable commercial products. Imported fertilizer and imported feed are input to the island and the present research would like to reduce these to enhance agricultural independence.

Substances in the material flow can be lost as gas (ex. $\mathrm{CO}_{2}, \mathrm{CH}_{4}, \mathrm{NH}_{3}$, etc.), as ion (ex. $\mathrm{NH}_{4}{ }^{+}$, etc.), as humus, or as inorganic substances in the soil or underground layers $\left(e x . \mathrm{Ca}_{3}\left(\mathrm{PO}_{4}\right)_{2}\right.$, etc.), during power generation, the composting process, the storage process, and during cud-chewing, breathing and fertilization.

Here we address the differences among nitrogen, carbon and phosphorus from the perspective of agriculture. Much of nitrogen is imported from outside of the island and the agricultural plants and beef cattle depend on it. Regarding carbon, agricultural plants do not require it because they do carbon fixation by photo synthesis whereas beef cattle need imported carbon. Beef cattle like calves need concentrate feeds imported from outside of the island because of the demand for high quality meat. Carbon is an energy source for the bacteria in the soil. Regarding phosphorus, much of imported phosphorus is assumed to stay in the soil as calcium phosphate and may be discussed in the future research.

Cattle urine is a soil and groundwater pollutant on Miyakojima Island. When unused urine evaporates into the air, it also causes unpleasant odors. When the unused urine seeps in the ground water, it pollutes the ground water. The present research suggests that it should be applied to the pasturage as liquid fertilizer instead of chemical fertilizer imported from outside of the island. This practice will make agriculture more sustainable by not only reducing agriculture's dependence on imported fertilizers, but it also has the added benefit of absorbing unused urine as fertilizer for pasturage to mitigate environmental impacts of soil and groundwater pollution and unpleasant odors.

Figure 9 shows the actual example of stockbreeding urine utilization as liquid fertilizer in Saga prefecture. Beef cattle are kept in the livestock barn on the left side of Figure 9. The gutter in the photo collects manure and urine. The photo also provides the inside view for the gutter. The gutter has two layers or sections: the upper section provides the space for manure whereas the lower section collects urine. The upper section is separated from the lower section by the steel plate or perforated grill. The urine collects in the lower section of the gutter and flows outside of the barn where it is stored in the reservoir. See Figure 10 for the AutoCAD drawing of the gutter, which shows its structure. The photo on the right side shows that urine is applied to oats and Italian ryegrass as a liquid fertilizer. Saga prefecture has many examples of utilization of urine as fertilizer for to pasturage.

Figure 9. Utilization of stockbreed urine as liquid fertilizer.
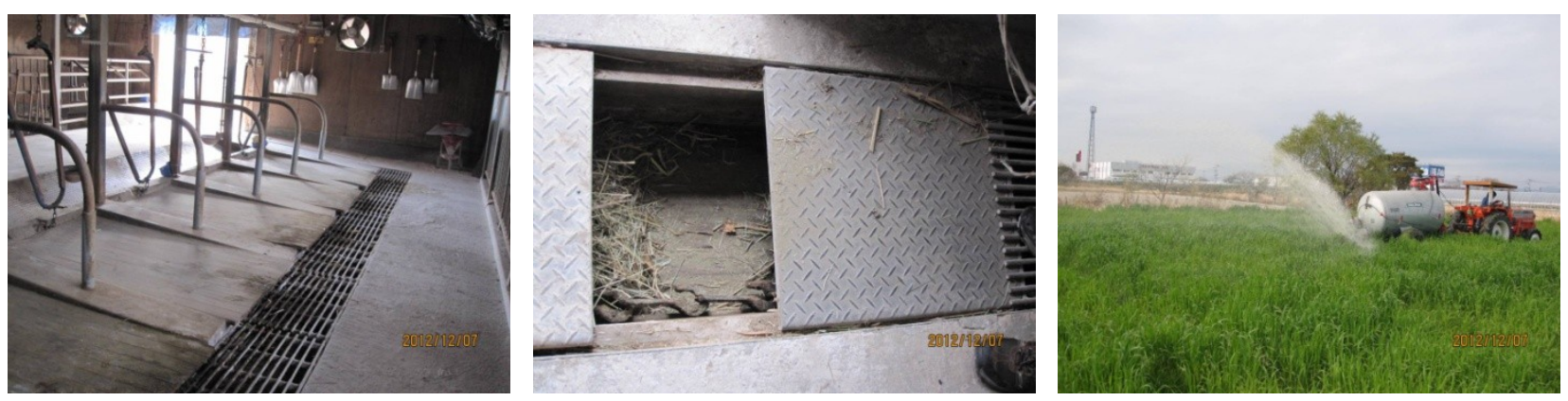
Advantages of using cattle urine are that the composting process is not required: losses in the storage process would be minimum. Moreover as previously discussed, the proper management and reuse of urine as pasturage fertilizer would help eliminate or reduce the negative environmental impacts of soil and groundwater pollution and odor problems associated with the current practices of urine. In the actual cases of urine application as liquid fertilizer in Saga prefecture, if bad odor issues arise, then the urine is diluted with water to mitigate the odor problems.

Figure 10. Drawing of stock breeding' gutter.

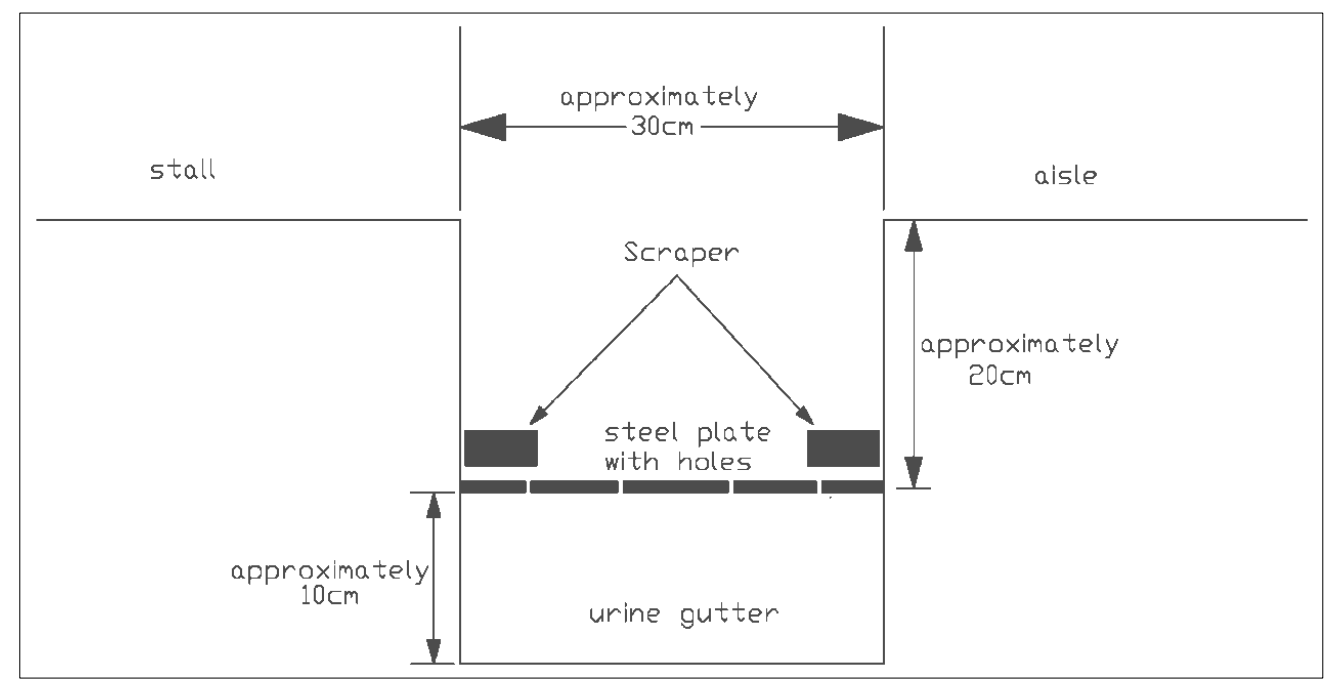

The photo on the left side of Figure 11 shows the raw materials of silage feeds: i.e., sugar cane tops and dried leaves. To cause lactic acid fermentation, the optimal water content is around $60 \%$, which can be controlled with dried leaves to adjust the water content. Examine the water content of the silage feed in Table 13: the water content of the silage is $61.5 \%$, which is appropriate for lactic acid fermentation. The photo in the middle of Figure 11 shows the actual appearance of silage feeds and the photo on the right side shows beef cattle eating silage feeds. The palatability of silage feeds seems to be good because the beef cattle readily ate all of the silage immediately.

Figure 11. Silage feeds created from sugar cane tops and dried leaves.
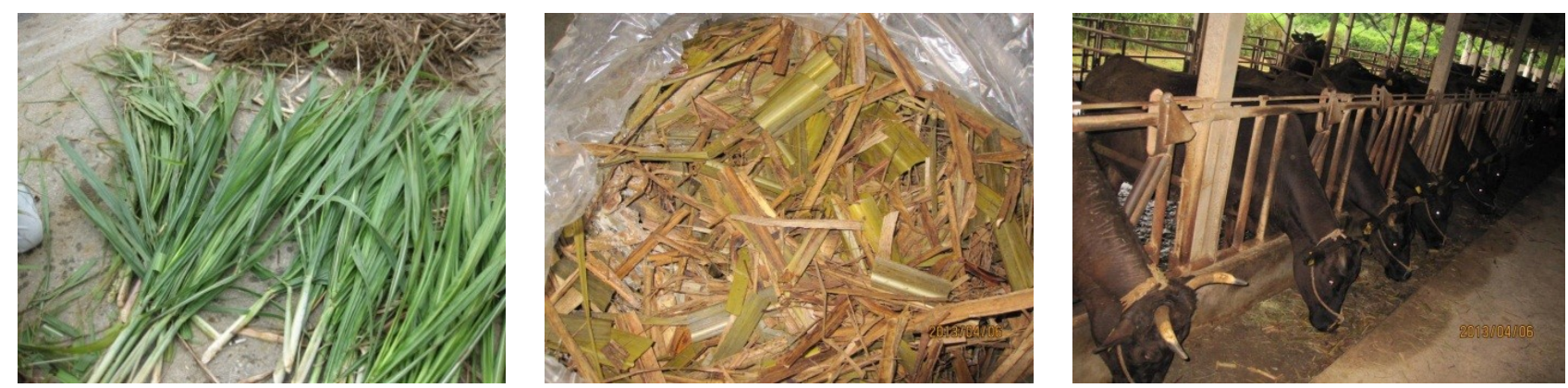

As shown in Table 13, the contents of the silage feeds created from the sugar cane residues are comparable to that of silage of Rhodes grass, which is one of the dominant grasses on Miyakojima Island. The compositions for silage of Rhodes grass are obtained from "Table of Feed Composition in Japan (2009)" [2]. 
Table 13. The composition comparison between silage feeds from sugar cane residues and silage rhodes grass [2].

\begin{tabular}{lcc}
\hline & $\begin{array}{c}\text { Silage Feeds Created from } \\
\text { Sugar Cane Residues (\%) }\end{array}$ & Silage Rhodes Grass (\%) \\
\hline Water Content & $\mathbf{6 1 . 5}$ & 74 \\
Crude Protein & $\mathbf{2 . 2 8}$ & 2.68 \\
Crude Fiber & $\mathbf{1 1}$ & 8.61 \\
Crude Fat & $\mathbf{0 . 8 9}$ & 0.57 \\
Nitrogen Free Extract & $\mathbf{2 2 . 8}$ & 10.6 \\
Sodium & $\mathbf{0 . 0 3}$ & 0.11 \\
Potassium & $\mathbf{0 . 5 4}$ & 0.93 \\
Magnesium & $\mathbf{0 . 0 6}$ & 0.06 \\
Calcium & $\mathbf{0 . 2 2}$ & 0.2 \\
Phosphorus & $\mathbf{0 . 0 9}$ & 0.25 \\
\hline
\end{tabular}

Another task would be to figure out to what extent the silage can meet the demand for pasturage on Miyakojima Island. Pasturage such as Italian rye grass, timothy and Bermuda grass is imported from outside of Miyakojima Island. The quantity of pasturage, which is imported from the outside of Miyakojima Island, is 741 tons. These imported grasses contain 7.6 ton of nitrogen however this nitrogen is not mandatory for pasturage.

Note that some pasturage is considered difficult to replace with resources on Miyakojima Island. Pasturage is fed to calves as hay after they are dried in the sun for 1 day to 4 days. Unfortunately pasturage fed to beef cattle that are over 10 months old must be dried further to achieve the targeted $15 \%$ water content. The reason why low water content hay is fed to beef cattle that are over 10 month old is to assure the quality of the meat: the pasturage which is not in the low water content, in other words hay, may change the meat color to a slight green. Drying hay sufficiently takes at least seven days and needs to be protected from rain completely during that time. One unrealistic method is to use greenhouses to produce the lower water content hay. The quantity of pasturage for beef cattle over 10 months old cannot be replaced with resources on Miyakojima Island is estimated 106 tons. Therefore, the total quantity of pasturage that need to be replaced with resources on Miyakojima Island is 635 ton.

Note that raw materials for the silage feeds in the present research are plowed under and create nutrient substances that are used for sugar cane cultivation. The present research thinks that the use for the beef cattle feed should be prior to being used for the composting because more ingredients are lost until being absorbed by agricultural plants in the composting process and fertilization.

\section{Conclusions}

The present research first conducts the MFA of stockbreeding such as chicken, pigs and dairy cattle. The used and unused biomass resources are demonstrated by the discussion in a quantitative manner: Manure from stockbreeding is used. The present research conducts the MFA of Miyakojima City Resource Recycling Center and is able to establish the loss ratio in the composting process of composting facilities. Other loss ratios are established, such as those of the storage process, the slurry process and the composting process in the soil. The present research also discusses the fertilizer distribution ratio and biomass distribution ratio as well. With these discussions, the present research demonstrates the 
material cycle between beef cattle, sugar cane and pasturage. Based on the result of the MFA, the present research makes two proposals: the first proposal is to utilize the unused urine as liquid fertilizer for pasturage; the second proposal is to utilize the sugar cane tops and dried leaves as silage feeds for beef cattle. $800 \mathrm{t} / \mathrm{y}$ of the chemical fertilizer and $635 \mathrm{t} / \mathrm{y}$ of roughage can be replaced and reduced. Although the silage feeds from sugar residues need more fertilizer from the outside, the silage feeds from sugar residues can reduce the imported material when we consider the material efficiency.

\section{Acknowledgments}

We take this opportunity to express our profound gratitude to Ryoujun Uechi, agricultural corporation Daifuku-Nouji, Narifuku-Youkeijou, Okisui Ltd., Atsuyuki Kawabe and Minamoto-Youton for the information about the stockbreeding and the agricultural plants. Our appreciation also goes to Shigeo Koide from Saga Agricultural College and Saga Prefectural Government for their support of the investigation. Our appreciation goes to Robert Marek for checking English. We are also obliged to staff members of Miyakojima City Hall and JA Okinawa Miyakojima District, JA Okinawa in Okinawa Main Island, Okinawa Seito, Miyako Seito and, for the valuable information provided by them in the agricultural administrative fields. Even though this paper is prepared in cooperation from many people given above but the responsibility of possible mistakes or errors is ours alone.

\section{Author Contributions}

Shuichi Tamura conducts investigations, elemental analysis and paper writing; Koichi Fujie made the overall direction and the review for the paper.

\section{Conflicts of Interest}

The authors declare no conflict of interest.

\section{Appendix}

\section{Appendix 1}

The nitrogen concentration can be obtained from the crude protein concentration from the following factor: we only divide the crude protein concentration by the factor [2,3,11]. This conversion factor is commonly utilized in the food industry.

Table A1. Nitrogen-to-protein conversion factors.

\begin{tabular}{lccc}
\hline & $\begin{array}{c}\text { all cattle feed (except } \\
\text { for milk for calves) }\end{array}$ & $\begin{array}{c}\text { meat ( live } \\
\text { cattle body) }\end{array}$ & $\begin{array}{c}\text { dairy product } \\
\text { (milk for calves) }\end{array}$ \\
\hline NPCF (nitrogen-to-protein conversion factor) & 6.25 & 5.55 & 6.38 \\
\hline
\end{tabular}

In the same way, to obtain the carbon concentration, we will use either (1), (2) or (3) factor from the following table. This is the original in the reference [11]. 
Table A2. Conversion factors to obtain carbon contents.

\begin{tabular}{l}
\hline total carbon $=($ soluble sugar content starch + hemicellulose + cellulose $) \times 0.435+$ \\
lignin $\times 0.65+$ crude protein $\times 0.53+$ crude fat $\times 0.77$ \\
(2) total carbon $=$ all carbohydrate $\times 0.435+$ crude protein $\times 0.53+$ crude fat $\times 0.77$ \\
(3) total carbon $=$ all carbohydrate $\times 0.435+$ protein $\times 0.53+$ fat $\times 0.77$ \\
\hline Note: $(1)$ all carbohydrate $=$ crude fiber + NFE(nitrogen free extract $)$ \\
(2) soluble sugar content starch $=$ all carbohydrate $-\mathrm{NDF}$ (neutral detergent fiber $)$ \\
(3) hemicellulose $=$ NDF (neutral detergent fiber $)-\mathrm{ADF}($ acid detergent fiber $)$ \\
(4) cellulose $=$ crude fiber \\
(5) lignin $=\mathrm{ADF}-$ crude fiber
\end{tabular}

\section{Appendix 2}

Figure 12 shows the MFA for the beef cattle. Because our previous research "An Evaluation of the Cattle Breeding Business in Miyakojima Island: Material Flow Analysis about Four Types of Cattle Breeding [1]" clarified the MFA for it, we just explain it briefly. The target period is one year. Pasturage, bagasse and sugar cane tops are roughage. Imported feeds are mainly consisted of concentrate feeds, i.e., seeds of cereal grain like corn. In section 3.3, we discuss how we can decrease the amount of imported feeds. Manure is plowed under as basal fertilizer. Urine is an unused biomass resource: Currently it is an environmental pollutant to the ground water or evaporates and is a source of bad odors. Some of the inputs and outputs are not shown for the convenience of the discussion in the present research such as milk fed by breeding cows to calves.

Figure A1. MFA for the Entire Beef Cattle.

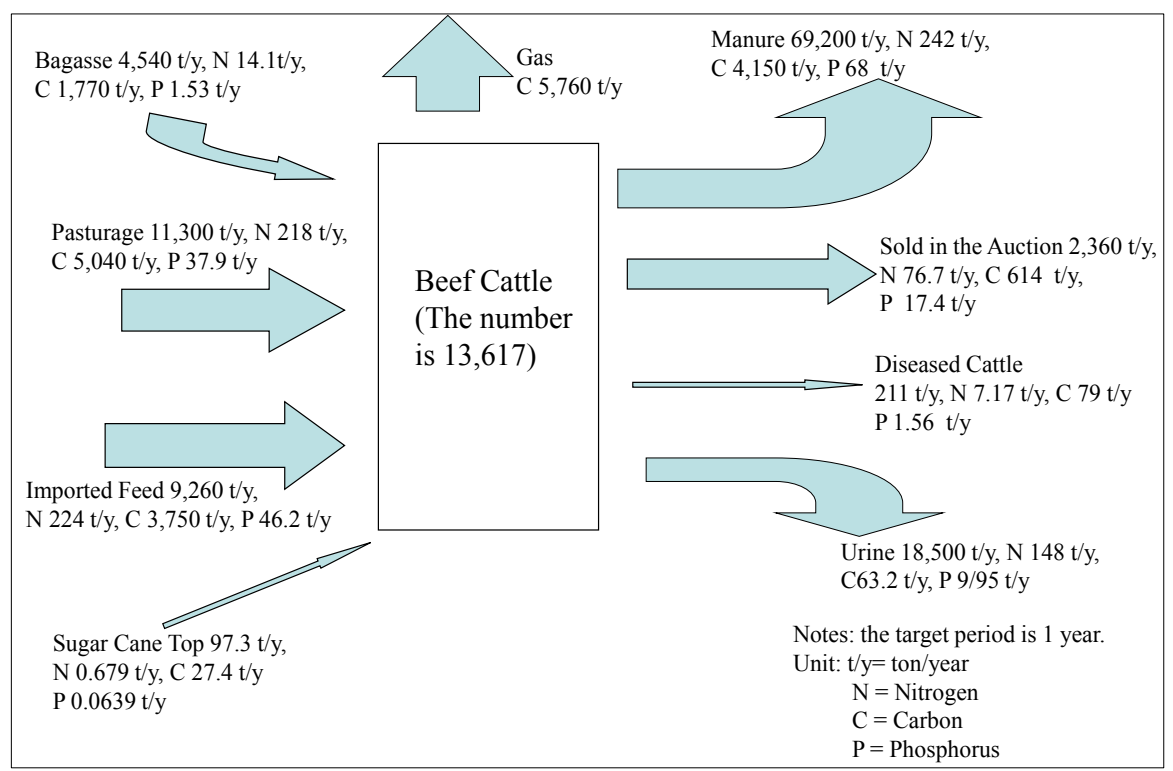

\section{Appendix 3}

Here we explain the Formula used to obtain the quantity of manure and urine generated by stockbreeding animals in Figure 13 that was given in the previous research [17]. This formula allows us to obtain the quantity of stockbreeding animal's manure and urine from the quantity of the nitrogen 
assigned for manure and urine. The quantity of the nitrogen assigned for manure and urine is obtained from the equation in (1). Each quantity of manure and urine is obtained from the equations in (2) and (3). For example, variable $\mathrm{X}$ is $5.36 \mathrm{t} / \mathrm{y}$ in Figure 3 of manure and $\mathrm{Y}$ is $2.94 \mathrm{t} / \mathrm{y}$ of urine in Figure 3. Variable V1 is the nitrogen quantity of "imported feed", which is $7.43 \mathrm{t} / \mathrm{y}$. W1 is "Go to the Meat Center or Sold in the Market", W2 is "Milk", 3.15 t/y and W3 is "diseased cattle", $0.228 \mathrm{t} / \mathrm{y}$. The constants a, b, c and d are shown in Table 3. Regarding Figure 12, the value 0.0035 for constant " $a$ " and 0.008 for constant $b$ is used. Therefore variable $\mathrm{T}$ is $1,530 \mathrm{t} / \mathrm{y}$ while variable $\mathrm{U}$ is $368 \mathrm{t} / \mathrm{y}$.

The difference is that it is adjusted not only to the beef cattle but to the other stockbreeding. We stated in Chapter 1 that the material balance of the nitrogen, carbon and phosphorus in the MFA for the present research was performed. One of the benefits is that the formula allows us to perform the material balance in the MFA. We are also able to get the quantity of manure and urine in accordance with the nitrogen quantity of the input into the stockbreeding when the material balance of the nitrogen, carbon and phosphorus is performed. For example, adult cattle is given more feeds and nitrogen than calves: accordingly adult cattle generates more manure than calves. Using formula in Figure 13, we can adjust the quantity of manure according to the quantity of feeds and nitrogen. It has another benefit. The quantity of manure obtained from stockbreeding farmers tends to be smaller than the quantity in the reference. ("Stockbreeding Great Encyclopedia" says the quantity of pig's manure is $3 \mathrm{~kg}$ /day but the actual quantity the farmers give $1 \mathrm{~kg}$ /day). Stockbreeding farmers in Miyakojima Island keep a log when they sell manure to farmers of agricultural plants like sugar canes. But at that time, manure is stored for the certain period of times and the quantity got smaller than the fresh manure. Manure was dehydrated and decomposed if it was stored in the outside. Also in accordance with the weight of stockbreeding, the quantity of manure is different. Although it is not easy to measure how much the quantity of manure is (it is true of the quantity of urine as well), the formula gives us more probable quantity of the manure and urine:

Figure A2. Formula to obtain the quantity of manure and urine of stockbreeding.

$$
\begin{aligned}
& \text { (1) } \mathrm{X}+\mathrm{Y}=\mathrm{Z}-\left(\mathrm{W}_{1}+\mathrm{W}_{2}+\ldots+\mathrm{W}_{\mathrm{n}}\right) \\
& \text { (2) } \mathrm{X} / \mathrm{a}: \mathrm{Y} / \mathrm{b}=\mathrm{c}: \mathrm{d} \\
& \text { (3) } \mathrm{T}=\mathrm{X} / \mathrm{a}, \mathrm{U}=\mathrm{Y} / \mathrm{b}
\end{aligned}
$$

Where:

$\mathrm{Z}=\mathrm{V}_{1}+\mathrm{V}_{2}+\ldots+\mathrm{V}_{\mathrm{m}}$

Variable $\mathrm{X}=$ Nitrogen Quantity contained in Manure

Variable $\mathrm{Y}=$ Nitrogen Quantity contained in Urine

Variable W = Items of Nitrogen Output except for Manure's an Urine's

Variable $\mathrm{V}=$ Items of Nitrogen Input

Variable T $=$ Quantity of Each Stockbreeding's Manure

Varialbe U = Quantity of Each Stockbreeding's Urine

Constant $\mathrm{a}=$ Nitrogen Concentration of Each Stockbreeding's Manure

Constant $b=$ Nitrogen Concentration of Each Stockbreeding's Urine

Constant $\mathrm{c}=$ Quantity Proportion of Each Stockbreeding's Manure against their Urine

Constant $\mathrm{d}=$ Quantity Proportion of Each Stockbreeding's Urine against their Manure 


\section{References}

1. UNU/Zero Emissions Research Initiative, United Nations University Website. Available online: http://www.ias.unu.edu/sub_page.aspx?catID=5\&ddlID=468 (accessed on 26 December 2013).

2. Table of Feed Composition in Japan (2009) (In Japanese); National Agriculture and Food Research Organization, Japan Livestock Industry Association: Ibaraki, Japan, 2010.

3. Standard Tables of Food Composition in Japan 2010 (In Japanese); Ministry of Education, Culture, Sports, Science and Technology, Government of Japan: Tokyo, Japan, 2010. Available online: http://www.mext.go.jp/b_menu/shingi/gijyutu/gijyutu3/houkoku/1298713.htm (accessed on 21 January 2013).

4. A Report for Biomass Unused Energy Business Survey (In Japanese); Miyakojima City Hall: Miyakojima-shi, Japan, 2006.

5. Morimoto, H. Revised Livestock Nutriology (In Japanese); Yokendo Co., Ltd.: Tokyo, Japan, 1996.

6. Nielsen, A. Anatomical and chemical composition of Danish Landrace pigs slaughtered at 90 kilograms live weight in relation to litter, sex and feed composition. J. Anim. Sci. 1973, 36, 476-483.

7. Zelenka, J. Allometric growth of calcium, phosphorus, magnesium, sodium, and potassium in slow- and fast-growing young chickens. Czech J. Anim. Sci. 2012, 57, 557-561.

8. Matsuzaki, T. Studies on the utilization of animal wastes in agriculture. Bul. Agric. Res. inst. Kanagawa Prefecture 1977, 118, 1-38, (In Japanese).

9. Naito, M. Stockbreeding Great Encyclopedia (In Japanese); Yokendo Co., Ltd.: Tokyo, Japan, 1989.

10. Takai, Y.; Hayase, T.; Kumazawa, K. Plant Nutrition Soil Fertilizer Great Encyclopedia; Yokendo Co., Ltd.: Tokyo, Japan, 1976.

11. Nakamura, M.;Yuyama, Y. Development of a composition database for various types of biomass. NIRE Rep. 2005, 203, 57-80, (In Japanese).

12. Feedipedia, The French National Institute For Agricultural Research. Available online: http://www.feedipedia.org/node/14533 (accessed on 21 January 2013).

13. Tarora, K.; Miyamaru, N.; Ota, M.; Ishjmine, M. Effects of green manure crops on the growth of next summer-planted sugarcane in early stages. Rep. Kyushu Br. Crop Sci. Soc. Japan 2005, 71, 75-77, (In Japanese).

14. Zakimi, T. Green Manure Plant Tests in Vacant Fields after Harvesting of Sugar Cane (in Japanese); Research Report of Okinawa Prefectural Agricultural Research Center: Itoman, Japan, 2000; pp. 322-333.

15. Nishimoto, M. Methane Fermentation Process for Treatment Distillation Residue; Technical Report of Ebara Corporation, Tokyo, Japan, 2009, 224, 25-27. Available online: http://www.ebara.co.jp/company/rd/jihou/pdf/224/224_P25.pdf (accessed on 21 October 2013).

16. Tanikawa, N. Present state of kitchen garbage in municipal waste. J. SHASE 2000, 74, 667-671, (In Japanese).

17. Tamura, S.; Maeda, R.; Fujie, K. An evaluation of the cattle raising business in Miyakojima Island: Material flow analysis about four types of cattle raising. Int. J. Environ. Sust. 2013, 9, 7-19. Available online: http://ijse.cgpublisher.com/product/pub.272/prod.47 (accessed on 17 October 2013).

18. Nishio, M. Estimation of flow sheet and load unit to farm soils of nitrogen excreted by animals on the basis of the national statistical data. J. Sci. Soil Manure Japan 2003, 74, 721-730, (In Japanese). 
19. Hao, X.; Chang, C.; Larney, F. Carbon, nitrogen balances and greenhouse gas emission during cattle feedlot manure composting. J. Environ. Qual. 2004, 33, 37-44.

20. Food and Agriculture Shown by Graph and Picture (In Japanese); Statistics Digest, Ministry of Agriculture, Forestry and Fisheries: Tokyo, Japan, 2002. Available online: http://www.toukei. maff.go.jp/dijest/tikusan/tiku04/tiku04.html (accessed 24 October 2013).

21. Yoshizawa, T.; Nakayama, K. Studies on soil science and fertilizer in the paddy field applied rice and barley straw. Tochigi Prefectural Agr. Exp. Stn. Res. Rep. 1983, 29, 49-60, (In Japanese).

22. Hojito, M.; Ikeguchi, A.; Kohyama, K.; Shimada, K.; Ogino, A.; Mishima, S.; Kaku, K. Estimation of nitrogen loading in Japanese prefectures and schnario testing of abatement strategies. J. Sci. Soil Manure 2003, 74, 467-474.

23. Okinawa Prefectural Government Fertilizer Application Standard. Available online: http://www.maff. go.jp/j/seisan/kankyo/hozen_type/h_sehi_kizyun/ (accessed on 24 October 2013).

(C) 2014 by the authors; licensee MDPI, Basel, Switzerland. This article is an open access article distributed under the terms and conditions of the Creative Commons Attribution license (http://creativecommons.org/licenses/by/3.0/). 